\title{
Perceptions of pregnant women about the role of partners in prenatal consultations*
}

\author{
Percepções de gestantes acerca da atuação dos parceiros nas consultas de pré-natal
}

Iarlla Silva Ferreira ${ }^{1}$, Ana Fátima Carvalho Fernandes ${ }^{1}$, Karísia Karen Ricarte L $\hat{0}^{1}$, Thaissa Pinto de Melo ${ }^{1}$, Altamira Mendonça Félix Gomes ${ }^{1}$, Ivna Silva Andrade ${ }^{1}$

Objective: to understand the perception of pregnant women about the role of partners in prenatal consultations. Methods: qualitative study with 15 pregnant women. Data was collected through non-participant observation and semi-structured interview, organized and analyzed based on Content Analysis technique. Results: the speeches were grouped into three categories: the presence of the father during the consultations as an adherence factor to prenatal care, the man's participation in the care of the pregnant woman and the child, and the partner as a confidence promoter. Conclusion: women reported feelings of safety and increased confidence when accompanied by partners in the consultations.

Descriptors: Prenatal Care; Paternity; Pregnancy.

Objetivo: compreender as percepções de gestantes acerca da atuação de parceiros nas consultas de prénatal. Métodos: estudo qualitativo com 15 gestantes coletados por observação não participante e entrevista semiestruturada, sendo organizados e analisados com base na Análise de Conteúdo. Resultados: os discursos foram agrupados em três categorias: presença do pai durante as consultas como um fator de adesão ao pré-natal, participação do homem nos cuidados da gestante e da criança, e parceiro como agente promotor de segurança. Conclusão: as mulheres relataram sentimentos de segurança e confiança aumentados, quando acompanhadas pelos parceiros nas consultas.

Descritores: Cuidado Pré-Natal; Paternidade; Gravidez.

\footnotetext{
*Extracted from the monography “Percepção de gestantes acerca da atuação dos parceiros nas consultas de pré-natal”, Universidade Federal do Ceará, 2015.

${ }^{1}$ Universidade Federal do Ceará. Fortaleza, CE, Brazil.

Corresponding author: Iarlla Silva Ferreira

Rua Alexandre Baraúna, 1115 - Rodolfo Teófilo. CEP: 60430-160. Fortaleza, CE, Brazil. E-mail: iarlla@live.com
} 


\section{Introduction}

Maternal and child care is a priority area for the Brazilian Ministry of Health, so that it has established as a top priority for prenatal care the welcoming from the beginning of pregnancy to ensure the birth of a healthy child and maternal and newborn's welfare ${ }^{(1)}$.

During this period, women become more sensitive to intrinsic and extrinsic events to pregnancy. Physical and emotional changes inherent to their condition bring needs to be met, require the participation and understanding of people close to them, especially the partner ${ }^{(2)}$.

As pregnant women often attend prenatal consultations unaccompanied, they become solely responsible for adhering to the service, the guidelines and the tests. One reason for this aspect is that health institutions still maintain routines and physical structures designed to meet the needs of employees and internal policy, targeting only those who receive the care ${ }^{(3)}$.

The experience of men in their partner's pregnancy comprises the interaction established with themselves, with the pregnancy, with their partner and the family. And to talk about the role of man in the contemporary context one must consider aspects that make up their perception and experience about fatherhood, among which there is the issue of gender, the transgenerational models and the coexistence of new social demands ${ }^{(4)}$.

Participation in prenatal consultation is an opportunity for fathers to feel closer, experiencing the gestation of the baby, so that the materialization of the child can happen, because without this experience they will only have a subjective perception through information obtained from mothers ${ }^{(3)}$.

In general, the circumstances surrounding the man's world, in which he presents himself as a provider, caregiver and head of the family, may pose a risk to the harmony of conjugal living ${ }^{(4)}$.

The insertion of men in spaces for understanding of self and others, of new social roles, such as those related to being a mother and being a father, has positive influence on their experiences, especially with regard to a more conscious and complete experience of their roles. This justifies the need for devising public policies and permanent actions on this theme in health institutions ${ }^{(5)}$.

In the context of pregnancy, receiving the other's attention, focusing on the analysis of their responses and the emotional and social problems of men requires an evaluative technique that considers the meanings and symbols built, considering the life experience of the couple under care ${ }^{(2)}$.

The Brazilian Ministry of Health has as one of the ten steps to a quality prenatal care the partner's right of being cared, which includes access to information before, during and after pregnancy ${ }^{(6)}$. However, there is gap in the literature with regard to the opinion of pregnant women on the theme, whether they consider important the presence of the father at the time of consultation and if so, how they would like them to participate.

From the above, this study aims to understand the perception of pregnant women about the role of partners in prenatal consultations.

\section{Methods}

This is a qualitative study, carried out from January to April 2015. The scenario was the Family Development Center of the Federal University of Ceará, located in Fortaleza, Brazil.

The study subjects were 15 women, chosen according to the following inclusion criteria: pregnant women receiving prenatal care in the institution. Underage women participated only with permission of a legal guardian.

The pregnant women were identified by the letter $\mathrm{P}$ and a sequence number, according to the order of interviews - 1 to 15.

Data collection occurred in two stages: nonparticipatory observation in prenatal consultation carries out by nurses; and semi-structured recorded 
interview, held after the consultation, consisting of socio-demographic and economic factors (age, marital status, occupation and income, among others), in addition to the specific questions of the study object.

The interviews were transcribed in full for the reliability and accuracy of reports.

The speeches were organized and analyzed based on the steps of content analysis technique: preanalysis and organization of the material; exploration of this material by the classification and coding or categorization; and interpretation of results ${ }^{(7)}$.

The study complied with the formal requirements contained in the national and international regulatory standards of research involving human subjects.

\section{Results}

From the analysis of the data identified three categories: The presence of the father during the consultations as an adherence factor to prenatal care; man's participation in care to the mother and the child and the partner as confidence promoter.

\section{The presence of the father during the consultations as an adherence factor to prenatal care}

Women reported feeling overburdened with responsibilities and information during service.

When asked about what the role of partners would be during prenatal consultations, most of the women said the man could participate actively in that moment, to clarify doubts and aggregation of new information, since during a prenatal consultation the health professional performs numerous guidance and information on the health of the child and the woman.

Thus, it is clear that pregnant women feel the need to distribute the prenatal responsibilities. So, the husband's presence also represents an incentive for pregnant women attend the recommended consultations.
Although women have the knowledge that prenatal care is a way to prevent or avoid complications during pregnancy, they usually feel afraid and expect support, which may come mainly from the partner. Asking the things I forget. I am shy, so, sometimes during consultation he asked the question for me. It is an aid, an incentive for pregnant women want to come in the next consultations (P7). When we come to the consultation the doctor speaks much, gives a lot of information about us and about the baby. And the child's father presence encourages us to come (P13). Very important because there is a lot that we do not know and when we come to prenatal care we receive information. Sometimes I do not want to come, so if he came with me it would be different (P3 e P14).

\section{Man's participation in care to the mother and the child}

Pregnant women realize that if their partners attended prenatal consultations, they would understand the physiological and pathological processes that underlie the pregnancy, then they would know how to act in emergency situations, for example.

And above that, when the child was born, the man would be more present in order to care for and assist the newborn. Since parents usually do not have experience and knowledge about how to care for a baby, the participation in prenatal care would help considerably.

So women believe that as the partner participated in consultations, the process of pregnancy and baby care would be clarified and attention and caring by men would be greater. Because he would know more things and would help me too. So it is a way to participate and stay attentive (P4 e P1). I like him to be aware of things. Stay informed! He would understand more the things that were happening to me, he would understand more. He already pays attention, but if he accompanied me, the care and attention would be greater (P6). It is important because he also learns and clears out his doubts (P11). Because he will learn and if anything happens, he will already know about (P14). 


\section{The partner as confidence promoter}

Most women reported that the presence of the partner during the prenatal consultations provides feelings of safety and confidence.

Pregnant women, whether they were primiparous or not, commonly expressed fear and insecurity in relation to pregnancy and the care of the newborn. Therefore, they agreed that the presence of the father during this process is of fundamental importance, as it provides credibility for pregnant women. Knowing that the person wants to participate, being present, already gives us confidence (P1). I find it important to accompany the mother and the baby, we feel safer (P2). It is good because it gives us confidence. And it is important for women to feel confident (P3 e P8).

\section{Discussion}

Although there is a current trend for parents to identify themselves as a pregnant couple from the beginning of pregnancy, seeking to have an active role in the pregnancy consultations or in preparation classes for childbirth ${ }^{(8)}$, this is not a reality in most couples, especially those with low socioeconomic status and education.

Corroborating the results, pregnant women and mothers revealed that the absence of the man in the pregnancy and delivery processes generated feelings of loneliness and emptiness ${ }^{(3)}$. Therefore, the involvement of men with pregnancy should be encouraged from the beginning of pregnancy so that men incorporate participatory attitudes of particular involving pregnancy ${ }^{(4)}$.

Men are able to take care and this is significant for them, because their perception of taking care is: being close, accompanying, being concerned, comforting, being reciprocal, enjoying leisure, dialoguing, living with the family and having attitudes of faith and religiosity ${ }^{(9)}$.

Moreover, it can be seen that fathers' involvement has a positive influence on prenatal care in some aspects, such as the abstinence from alcohol and tobacco, and reduction in low birth weight and small children for gestational age ${ }^{(10)}$.

The father may also contribute to the practice of breastfeeding through his attitude towards the children, his wife and housework. But for that, some issues must be deeply considered so that there is a greater understanding among fathers about the breastfeeding process ${ }^{(11)}$. These issues must be addressed and discussed with the couple during prenatal consultations.

There is the need of the father's insertion in this context, because the lack of understanding of some characteristic phenomena of pregnancy, especially on the physiological foundations of the emergence of different signs and organic symptoms, contributes to lack of maintenance of peace in relation to fathers and brings a justification for them are not deeply involved with this process $^{(6)}$.

Therefore, knowledge of men about the care related to pregnancy and a positive attitude improves women's decisions about care to their health and the child's health ${ }^{(12) .}$

However, the father must be accessible and engaged during pregnancy and begin to demonstrate responsibility to the child coming, helping the mother. For, as all involvement is through the mother, who bears the child, then the relationship between the two is relevant and determining in the level of involvement of fathers ${ }^{(13)}$.

Besides the absence of the partner in prenatal care causes insecurity and fear, as pointed out by this study, it can also, according to the reality that surrounds the couple in the context of reproduction, predisposes pregnant women to strengthening the discomforts arising from the pregnancy and thus goes against their well-being, in addition to bringing the possibility of imbalance in the couple relationship ${ }^{(4)}$.

It is noticed that the gender issue is still a major factor, which refers to the traditional paternity, since it is rooted in the male culture. It is observed that most are still linked to the conception of man as provider ${ }^{(14)}$. 
But in experiments in which fathers actively participated in group work developed during the prenatal care, shared experiences and could realize that other men also experienced similar situations there was promotion of the quality of the relationship between the couple and involvement with pregnancy and the role of father ${ }^{(6)}$. This intensifies the perception of pregnant women that men's participation during this period contributes to family well-being as a whole. This understanding leads to the need for health professionals, who provide care to women during pregnancy, value and stimulate the inclusion of men in prenatal care, as recommended by the Ministry of Health $^{(4)}$.

Therefore, it is essential that men have easier access to these services, feel welcomed and encouraged to participate in the consultations and educational groups, and present concrete reasons to encourage other parents to also participate ${ }^{(6)}$. So, one should consider the importance of health professionals as facilitators of this participation, emphasizing the need of man/father in the pregnancy, ruling out the idea of man as only a provider of material needs, and to make them feel part of the pregnancy process ${ }^{(5)}$.

As Brazil has invested in a qualified and humanized prenatal care policy, the importance of man in the prenatal monitoring should be recognized and widely publicized and stimulated ${ }^{(15)}$.

Whereas the monitoring of pregnancy demands care with the woman, spouse and family, fathers' behavior with respect to pregnancy should be valued as a direct contributing factor in the welfare of pregnant women ${ }^{(3)}$, agreeing thus with the understanding of women on the participation of men during pregnancy.

\section{Conclusion}

For pregnant women, the importance of prenatal care is based on the precept that the consultation is the time to assess the health of the baby and the women, and to receive information on feeding, care of the newborn, among other issues.

With regard to the presence of the partner during this period, there is consensus and the majority of pregnant women prefer to have the presence of partners during prenatal care.

\section{Collaborations}

Ferreira IS, Melo and TP and Lô KKR contributed to the collection of field data. Andrade IS contributed to analysis and interpretation of data. Gomes AMF and Fernandes AFC contributed to the writing of the article, relevant critical review of the intellectual content and final approval of the version to be published.

\section{References}

1. Shimizu HE, Lima MG. As dimensões do cuidado pré-natal na consulta de enfermagem. Rev Bras Enferm. 2009; 62(3):387-92.

2. Silva FCB, Brito RS. Percepção de gestantes acerca das atitudes do companheiro diante da ausência no pré-natal. Rev Rene. 2010; 11(3):95-102.

3. Pesamosca LG, Fonseca AD, Gomes VLO. Percepção de gestantes acerca da importância do envolvimento paterno nas consultas prénatal: um olhar de gênero. Rev Min Enferm. 2008; 12(1):182-8.

4. Oliveira SC, Ferreira JG, Silva PMP, Ferreira JM, Seabra RA, Fernando VCN. A participação do homem/pai no acompanhamento da assistência pré-natal. Cogitare Enferm. 2009; 14(1):73-8.

5. Reberte LM, Hoga LAK. A experiência de pais participantes de um grupo de educação para saúde no pré-natal. Cienc Enferm. 2010; 16(1):105-14.

6. Ministério da Saúde (BR). Atenção ao pré-natal de baixo risco. Brasília: Ministério da Saúde; 2012.

7. Bardin L. Análise de conteúdo. Lisboa: Edições 70; 2011.

8. Nogueira JDF, Ferreira M. O envolvimento do pai na gravidez/parto e a ligação emocional com o bebé. Rev Enf Ref. 2012; 3(8):57-66. 
9. Silva SO, Budó MLD, Silva MM. Care concepts and practices from men's viewpoint. Texto Contexto Enferm. 2013; 22(2):389-96.

10. Alio AP, Salihu HM, Kornosky JL, Richman AM, Marty PJ. Feto-infant Health and Survival: Does Paternal Involvement Matter? Matern Child Health J. 2010; 14(6):931-7.

11. Jeneral RBR, Bellini LA, Duarte CR, Duarte MF. Aleitamento materno: uma reflexão sobre o papel do pai. Rev Fac Ciênc Med Sorocaba. 2015; 17(3):140-7.

12. Chattopadhyay A. Men in maternal care: evidence from India. J Biosocial Sci. 2012; 44(1):129-53.
13. Alio AP, Lewis CA, Scarborought K, Harris K, Fiscella K. A community perspective on the role of fathers during pregnancy: a qualitative study. BMC Pregnancy Childbirth. 2013; 13(60):2-11.

14. Oliveira EMF, Brito RS. Ações de cuidado desempenhadas pelo pai no puerpério. Esc Anna Nery. 2009; 13(3):595-601.

15. Ferreira TN, Almeida DR, Brito HM, Cabral JF, Marin HA, Campos FMC, et al. A importância da participação paterna durante o pré-natal: percepção da gestante e do pai no município de Cáceres-MT. Rev Eletr Gestão Saúde [Internet]. 2014 [citado 2015 set 20]; 5(2):337-45. Disponível em:http://gestaoesaude.unb.br/index.php/ gestaoesaude/article/view/622/pdf 